\title{
PENGEMBANGAN HOME INDUSTRY TEMPE “KERATON" DESA MONTORNA
}

\author{
Faisol Aziz ${ }^{1 *}$, Insusmoko Adi Jansen, Mohammad Aliridla \\ Prodi Agribisnis Fakultas Pertanian Universitas Wiraraja \\ Jalan Raya Sumenep-Pamekasan KM. 05 Patean, Batuan, Sumenep - Jawa Timur 69451 \\ isholdanista@gmail.com
}

\begin{abstract}
ABSTRAK
Usaha tempe merupakan salah satu home industry yang mampu menyerap tenaga kerja dengan jumlah yang cukup besar. Penyerapan tenaga kerja umumnya terkait langsung pada bagian produksi, selanjutnya bagian penjualan. Penyerapan tenaga kerja yang cukup banyak menjadi potensi yang sangat besar untuk dikembangkan. Home Industry tempe di Desa Montorna Kecamatan Pasongsongan selain berpotensi unuk dikembangkan, namun saat ini masih memiliki kelemahan dalam manajemen serta jumlah modal yang dimiliki, sehingga perlu adanya upaya perbaikan melalui strategi pengembangan agar dapat bersaing khususnya untuk mendapatkan pangsa pasar. Pemilihan lokasi penelitian dilakukan secara sengaja dengan berbagai pertimbangan tertentu bahwa perusahaan tersebut akan mampu bersaing dalam pangsa pasar dari segi produksinya. Sampel penelitian ditentukan secara sensus karena hanya ada satu populasi. Strategi pengembangan ditentukan dengan menggunakan analisis SWOT. Berdasarkan hasil penelitian yang dilakukan di Perusahaan Home Indusry tempe "keraton" di desa montorna kecamatan pasongsongan dapat di tarik kesimpulan bahwa strategi pengembangan usaha Home Indusry tempe, adalah strategi agresif yaitu meningkatkan manajemen serta jumlah dan kualitas produksi untuk mendapatkan kepercayaan dari konsumen.
\end{abstract}

Kata Kunci: Pengembangan, home industry, tempe

\section{ABSTRACT}

Tempeh industry is a small industry that is able to absorb a large number of workers both directly related to the production process and related to trade in materials which are inputs and processed products. Tempe industry is one of the household agro-industries that has great potential to be developed. The tempe industry in montorna village, Pasongsongan subdistrict is still a small industry that has weaknesses in management and the amount of capital it has, so efforts should be made to improve its development strategy. able to compete in gaining market share; The location of the research was carried out intentionally (purposive) in the "Keraton" tempeh in Montorna village, Pasongsongan District with various specific considerations that the company would be able to compete in market share in terms of production. Because the population is only 1 (one), all populations are sampled using census or saturated samples. Based on the results of research conducted at the Home Industry Company tempe "palace" in the village of Montorna Pasongsongan District can be concluded that the strategy of Home Tempus Home Business development, is an aggressive strategy that is improving management and the number and quality of production to gain the trust of consumers.

Keywords: Development, home industry, tempeh 


\section{PENDAHULUAN}

Sektor industri kecil adalah salah satu penyumbang PDB Indonesia. Salah satu dari sektor industi yang cukup pesat pertumbuhannyadari segi jumlah adalah industri pangan. Industri pangan merupakan industri yang mengolah atau mengawetkan hasil pertanian, perikanan dan peternakan menjadi produk pangan olahan untuk menciptakan nilai tambah. Kedelai merupakan bahan hasil pertanian yang diproduksi menjadi tempe oleh home industry tempe Keraton. Produksi tempe keraton berlokasi di Kecamatan Pasongsongan yang tepatnya di Desa Montorna juga termasuk dalam industri pangan yang cukup banyak pesaingnya karena, di Kabupaten Sumenep home industri tempe telah berdiri sejak lama.

Tempe termasuk salah satu favorit makanan disemua kalangan masyarakat karena selainrasanya yang lezat, tempe juga termasuk sumber protein nabati yang harganya relatif murah dibandingkan protein hewani. Seiring berkembangnya waktu, tempe tidak hanya digunakan sebagai lauk pauk namun juga diolah menjadi produk olahan seperti keripik tempe. Banyaknya konsumsi tempe di masyarakat serta berkembangnya produk olahan tempe menjadikan home industry tempe untuk tetap memproduksi tempe bahkan meningkatkan volume produksi bila perlu.

Dalam pengembangan usaha, home industry menghadapi berbagai kendala yang dihadapi mengingat banyaknya pesaing dari usaha kecil dan mengah hingga usaha besar. Banyaknya pesaing tersebut menuntut usaha tempe keraton untuk tetap berdaya saing. Untuk itu, itu home industry tempe keraton tersebut membutuhkan penerapan manajemen yang baik, dalam penelitian ini diupayakan melalui perumusan strategi pengembangan usaha yang dapat dilaksanakan oleh pihak manajemen home industry tempe keraton .

Salah satu home industry yang bergerak dalam pengolahan kedelai menjadi tempe dengan brand Tempe keraton saat ini masih merupakan industri kecil yang memiliki kelemahan dalam manajemen serta jumlah modal yang dimiliki, sehingga perlu dilakukan upaya-upaya perbaikan dengan perumusan strategi pengembangan agar dapat bersaing untuk mendapatkan pangsa pasar. Strategi pengembangan home industry tempe keraton merupakan suatu upaya dalam hal meningkatkan kontribusi home industry dalam perekonomian daerah dan nasional.

\section{METODE}

Sampel penelitian ditentukan secara sengaja (purposive) yaitu pada usaha tempe "Keraton". Lokasi penelitian yaitu pada home industry tempe Keraton yang dipilih secara sengaja yang terletak di Desa Montorna Kecamatan Pasongsongan. Pemilihan home industry tempe Keraton sebagai objek dan lokasi penelitian didasarkan atas pertimbangan bahwa akan mampu bersaing dalam pangsa pasar ditinjau berdasarkan aspek produksinya.

Karna jumlah populasi Cuma 1 (satu) maka semua populasi menjadi sampel yaitu dengan menggunakan metode sensus atau sample jenuh. Data dalam penelitian terdiri dari data primer dan data sekunder.

a. Data Primer

merupakan sumber data yang diperoleh langsung dari dari pemilik dan karyawan pada home industry tempe Keraton di Desa Montorna Kecamatan Pasongsongan.

1. Observasi

Metode pengumpulan data yang digunakan dengan cara melakukan 
pengamatan terhadap objek penelitian yaitu home industry tempe Keraton.

2. Wawancara

Melakukan Tanya jawab terhadap pimpinan perusahaan untuk mengidentifikasi strategi pengembangan yang diterapkan di lokasi penelitian.

\section{Kuisioner}

Pengumpulan data ini dilakukan dengan memberikan kuisioner atau pertanyaan kepada pengusaha tempe "Keraton" tentang pengembangan produksi tempe keraton di Desa Montorna Kecamatan Pasongsongan.

\section{b. Data Sekunder}

yaitu data yang diperlukan untuk mendukung data primer yang didapatkan melalui referensi maupun sumber informasi dan data yang terkait dengan penelitian.

\section{Analisis Data}

Metode analisis data yang digunakan dalam penelitian ini yaitu analisis internal eksternal menggunakan SWOT. Analisis Strenghts, Weakness, Opportunities dan Threats (SWOT) atau biasa disebut dengan TOWS adalah analisis yang dapat digunakan untuk menyusun berbagai faktor strategis dalam suatu perusahaan.

Analisis SWOT dapat menghasilkan empat set kemungkinan alternative strategis, yaitu Strategi 1 yang terdiri dari strenghts/Kekuatan, opportunities/peluang, strategi 2 terdiri dari weakness/kelemahan, opportunities/peluang, strategi 3 terdiri dari strenghts/kekuatan threatsi/ancaman dan strategi 4 yaitu weakness/kelemahan, threats/ancaman.(Rangkuty, 2006)
Strategi SO disusun dengan menyesuaikan pada jalan pikiran perusahaan, melalui pendayagunaan kekuatan internal perusahaan dalam memanfaatkan peluang yang ada sebesarsebesarnya. Dalam WO srategi diterapkan berdasarkan pemanfaatan peluang yang ada melalui minimalisasi kelemahan internal perusahaan. Strategi ke 3 yaitu ST merupakan strategi yang mendayagunakan kekuatan yang ada pada perusahaan untuk mengatasi ancaman eksternal. Strategi ke 4 yaitu WT adalah strategi yang bersifat defensive dan berusaha dengan meminimumkan kelemahan agar mampu menghindari ancaman dari luar.

Hasil dari analisis SWOT yang dilakukan adalah rumusan strategi berbagai alternative yang dapat terapkaan home industry tempe Keraton. Langkah analisis dalam penelitian yaitu dengan menyusun $\mathrm{m}$ atriks SWOT, yang terdiri dari:

\section{Analisis Faktor Internal (IFAS)}

a. Dalam analisis faktor internal, terlebih dahulu dilakukan identifikasi atas kekuatan, kelemahan, peluang dan ancaman perusahaan. Hasil identifikasi selanjutnya dituliskan pada masingmasing kolom dalam matriks SWOT (Strenghts, Weakness, Opportunities dan Threats).

b. Strategi SO dibuat berdasarkan jalan pikiran perusahaan, yaitu dengan memanfaatkan kekuatan untuk meraih peluang yang ada.

c. Strategi WO diterapkan berdasarkan pemanfaatan peluang dengan upaya meminimumkan kelemahan yang dimiliki perusahaan.

d. Kekuatan dan ancaman dijadikan strategi dengan cara memanfaatkan kekuatan saat ini dimiliki 
perusahaan untuk mengatasi adanya ancaman faktor ekstrenal.

e. Kelemahan dan ancaman dijadikan suatu strategi berupa meminimalkan kelemahan untuk dapat menghindari ancaman dari faktor eksternal.

\section{Analisis Faktor Eksternal (EFAS)}

Adapun tahapan dalam analisis faktor eksternal antara lain:

1. Penentuan faktor internal perusahaan yang menjadi kekuatan (Strenght) dan kelemahan (Weakness).

2. Penentuan faktor eksternal yang dapat menjadi peluang (Opportunity) dan ancaman (Threatment) bagi home industry Tempe Kerataon.

3. Pemberian nilai bobot terhadap masing-masing faktor internal dan eksternal dengan skala mulai dari 1,0 - 0,0. (Paling penting - tidak penting). Nilai Bobot nilai didasarkan atas pengaruh masing-masing faktor terhadap posisi strategis perusahaan.

4. Penghitungan rating pada masing-masing faktor kekuatan dan peluang dengan cara memberikan skala $4-1$ (outstanding - poor). Adapun penilaian terhdapa rating kelemahan dan ancaman adalah kebalikannya, dengan kriteria sebagai berikut:

a. Variabel yang termasuk dalam kategori kekuatan diberi tanda positif dengan nilai mulai dari 1 - 4 (tidak kuat - sangat kuat). 1 artinya tidak kuat, 2 artinya kuat, 3 cukup kuat dan sangat kuat.

b. Variabel dalam kategori kelemahan diberi tanda negatif dengan nilai mulai dari 1 - 4 (sangat lemah lemah).

c. Variabel dalam kategori peluang diberi tanda positif dengan penilaian 1 - 4 (tidak berpeluang hingga sangat berpeluang).

d. Variabel yang termasuk dalam kategori ancaman dimasukkan dalam kategori negatif dan diberi nilai $1-4$ (sangat mengancam tidak mengancam).

5. Pengalian masing-masing bobot dengan rating untuk memperoleh faktor pembobotan dalam kolom nilai. Hasilnya berupa skor pembobotan untuk masingmasing faktor yang nilainya bervariasi dari $0,4-0,1$.

6. Mengisi kolom komentar dengan memberikan keterangan berupa catatan mengapa faktor-faktor tertentu dipilih dan bagaimana skor pembobotan dari masingmasing faktor dihitung.

7. Penjumlahan skor pembobotan agar diperoleh total skor pembobotan bagi home industry Tempe Keraton.

\section{Definisi Operasional}

Definisi opersional mencakup pengertian untuk memperjelas beberapa istilah yang digunakan dalam penelitian ini :

1. Analisis SWOT merupakan analisis yang dipakai dalam menyusun 
faktor-faktor strategi perusahaan (Ling, 2013; Noor, 2014).

2. Kedelai adalah salah satu tanaman polong-polongan yang menjadi bahan dasar pembuatan tempe.

3. Tempe adalah makanan hasil fermentasi yang terbuat dari bahan baku ragi dan kedelai (Wilandari, 2010).

4. Home industry adalah rumah usaha produk barang atau juga perusahaan kecil. Dikatakan sebagai perusahaan kecil karena jenis kegiatan ekonomi ini di pusatkan dirumah. Home industry juga dapat berarti industri rumah tangga, karena termasuk dalam kategori usaha kecil yang dikelola keluarga.

5. Strategi adalah tools yang digunakan dalam mencapai tujuan. Konsep dalam strategi terus mengalami perkembangan.

6. Strategi yang diterapkan untuk suatu pengembangan usaha berupa pola atau perencanaan yang mampu mengintegrasikan sasaran perusahaan, kebijakan dan tindakan-tindakan organisasi secara kohesif, kegiatan tersebut dilakukan ke arah yang lebih baik dari keadaan sebelumnya.

7. Kuadran I merupakan strategi agresif yang berupa SO, dalam hal ini menggunakan kekuatan untuk meraih peluang yang ada.

8. Kuadran II merupakan strategi kompetitif yaitu ST, dalam hal ini menghindari ancaman dengan kekuatan yang dimiliki perusahaan.

9. Kuadran III adalah strategi konservatif yaitu mencakup WO yang merupakan strategi dengan orientasi putar balik yang terdiri dari gabungan antara kelemahan dan peluang.
10. Kuadran IV adalah strategi defensif yaitu WT, dalam hal ini gabungan antara kelemahan dan ancaman sebagai acuan untuk menyusun strategi pengembangan.

\section{HASIL DAN PEMBAHASAN}

\section{Kondisi Internal}

Analisis SWOT terhadap kondisi internal yaitu penggambaran atas kekuatan (Strenght) dan kelemahan (Weakness) yang yang ada pada home industry tempe Keraton. Untuk mengetahui aspek-aspek yang teridentifikasi sebagai kekuatan dan kelemahan dalam usaha home industry tempe Keraton dilakukan wawancara terhadap pihak internal yang terdiri dari pemilik beserta karyawan. Adapun aspek yang teridentifikasi sebagai kekuatan dan kelemahan yaitu sebagai berikut:

\section{Kekuatan (Strenght)}

a. Produk tahan lama

b. Harga ekonomis

c. Proses pembuatannya mudah

d. Kualitas produk terjamin

e. banyaknya stok produksi terjual

2. Kelemahan (Weakness)

a. Modal kurang

b. Kemasan sederhana

c. Manajemen tidak efektif

d. Kurangnya promosi

e. Lahan pemasaran yang tidak tetap

\section{B. Kondisi Eksternal}

Kondisi eksternal home industry tempe Keraton diidentifkasi dan digambarkan peluang (Opportunity) dan ancaman (Threats) yang dihadapi. Analisis SWOT di lingkungan eksternal dilakukan untuk mengetahui seberapa besar peluang dan ancaman dalam usaha home industry tempe adalah sebagai berikut :

\section{Peluang (Opportunity)}


a. Peluang pasar

b. Animo masyarakat terhadap tempe

c. Permintaan meningkat

d. Kepercayaan konsumen

e. produk merupakan makanan ciri khas daerah

2. Ancaman (Threats)

a. Adanya pesaing baru

b. Berubahnya selera konsumen

c. Bahan baku mahal

d. Fluktuasi permintaan konsumen

e. tidak stabilnya bahan baku

Berdasarkan data hasil wawancara dan diskusi terkait kondisi internal dan eksternal pada home industry tempe Keraton maka dapat disimpulkan bahwa home industry tempe Keraton Desa Montorna Kecamatan Pasongsongan perlu dikembangkan. Selanjutnya untuk pengembangan usaha dapat disusun strategi pengembangan dengan menggunakan SWOT sebagai upaya untuk menemukan alternative stategi baru yang dapat mendukung upaya pengembangan home industry tempe Keraton. Analisis SWOT meliputi tahapan identifikasi terhadap beberapa faktor internal maupun eksternal (Manurung \& Aryani, 2017).

\section{Penentuan Bobot Kondisi Internal}

Penentuan bobot merupakan proses yang dilakukan untuk menentukan strategi melalui analisis SWOT. Bobot ditentukan pada masing-masing nilai IFAS dan EFAS (Wilandari, 2010). Berdasarkan analisis lingkungan internal dan analisis lingkungan eksternal, maka langkah selanjutnya adalah penentuan bobot matrik SWOT. Bobot matrik SWOT ini diperoleh dari penentuan faktor-faktor analisis lingkungan internal (Strength, Weakness) dan faktor-faktor analisis lingkungan eksternal(Opportunity, Threats) yang lebih urgen, kemudian dijumlahkan dan dipersentase. Hasil dari penentuan bobot dari analisis kondisi internal (Strength, Weakness) dapat dilihat pada Tabel1.

Tabel 1. Bobot Analisis Kondisi Internal

\begin{tabular}{c|l|c}
\hline \multicolumn{2}{c|}{$\begin{array}{c}\text { Analisis Lingkungan } \\
\text { Internal }\end{array}$} & $\begin{array}{c}\text { Bobot } \\
(\%)\end{array}$ \\
\hline $\mathbf{S}$ & Kualitas produk terjamin & 20,00 \\
\cline { 2 - 3 } $\mathbf{W}$ & Manajemen tidak efektif & 8,89 \\
\hline \multicolumn{2}{|c}{ Kualitas produk terjamin }
\end{tabular}
faktor penting bagi home industry tempe Keraton sebagai kekuatan dengan bobot $20 \%$. Sementara kelemahan yang penting untuk di perbaiki adalah manajemen yang tidak efektif dengan bobot 8,89. Berdasarkan hal tersebut maka kedua faktor tersebut dijadikan acuan dalam penetuan skor matriks.

\section{Penentuan Bobot Kondisi Eksternal}

Penentuan bobot kondisi eksternal dirumuskan untuk penentuan bobot matrik SWOT. Penentuan bobot kondisi eksternal (peluang dan ancaman (Opportunity, Threats) sebagaimana pada Tabel 2.

Tabel 2. Bobot Analisis Kondisi Eksternal

\begin{tabular}{c|l|c}
\hline \multicolumn{2}{c|}{ analisis lingkungan eksternal } & $\begin{array}{c}\text { Bobot } \\
(\%)\end{array}$ \\
\hline \multirow{2}{*}{ O } & Peluang pasar & 20,00 \\
\cline { 2 - 3 } T & Perubahan selera konsumen & 8,89 \\
\hline
\end{tabular}

Hasil pemilihan faktor yang lebih penting dari matrik SWOT analisis kondisi eksternal (Opportunity, Threats) yaitu peluang pasar dan perubahan selera konsumen dengan bobot untuk peluang $20,00 \%$ dan ancaman $8.89 \%$. Perumusan strategi pengembangan selanjutnya mengacu pada tabel 1 dan 2 untuk menentukan skor matrik SWOT. Bobot analisis kondisi eksternal dan internal merupakan nilai bobot 
dari IFAS dan EFAS (Riska, Primyastanto, \& Abidin, 2015).

\section{Penentuan Skor}

Penentuan skor analisis kondisi internal (Strength/Weakness) dan analisis kondisi eksternal (Opportunity/Threats) diperoleh dari hasil kali bobot dan rating. Skor dengan nilai 4 dapat dikatakan sangat berpengaruh, skor dengan nilai 3 dapat dinyatakan berpengaruh dan skor 2 kurang berpengaruh dengan nilai 2 sedangkan skor 1 dinyatakan tidak berpengaruh dengan nilai 1 .

Total skor dari analisis kondisi internal Strength (kekuatan) secara keseluruhan adalah 271,12, sedangkan dari Weakness (kelemahan) adalah 53,33 dapat dilihat di tabel 4.3 dan analisis lingkungan eksternal dari Opportunity (peluang) secara keseluruhan adalah 235,34 sedangkan dari Threats (ancaman) adalah 44,44 dapat dilihat pada Tabel 3.

Tabel 3. Skor Analisis Kondisi Internal

\begin{tabular}{c|l|c}
\hline \multicolumn{2}{c|}{$\begin{array}{c}\text { Analisis Lingkungan } \\
\text { Internal }\end{array}$} & Skor \\
\hline \multirow{2}{*}{ S } & $\begin{array}{l}\text { Kualitas produk } \\
\text { terjamin }\end{array}$ & 80,00 \\
\cline { 2 - 3 } \multirow{2}{*}{ W } & $\begin{array}{l}\text { Manajemen tidak } \\
\text { efektif }\end{array}$ & 26,67 \\
\hline
\end{tabular}

Tabel 3 menunjukkan pada faktor kondisi internal yang berupa kekuatan yang paling dominan yaitu kualitas produk terjamin dengan nilai 80,00. Dengan demikian maka dapat dinyatakan bahwa dengan diproduksinya tempe yang kualitasnya terjamin tempe Keraton, maka akan sangat menentukan volume penjualan tempe Keraton untuk kedepannya. Untuk itu penting mempertahankan ditingkatkan kualitas produk tempe Keraton agar tetap menjadi kekuatan utama dalam pengembangan usahanya. Kualitas produk yang terjamin bahkan apabila semakin ditingkatkan kualitasnya maka akan semakin berkembang dan menjadi produk tempe pilihan utama untuk dibeli oleh masyarakat.

Faktor kelemahan pada home industry tempe kedelai yang memiliki nilai dengan skor tertinggi adalah Manajemen tidak efektif dengan skor 26,67dimana dengan Manajemen tidak efektif perusahaan harus meningkatkan kualitas manajen perusahaan agar mampu bersaing dalam memperoleh pangsa pasar. Manajemen sangat penting dalam suatu usaha termasuk usaha perseorangan sehingga salah satu strategi pengembangannya adalah dengan memperbaiki aspek manajemen usaha (Kristanto, Muliawati, Arief, \& Hidayat, 2018; Riska et al., 2015).

Tabel 4 disajikan analisis kondisi eksternal home industry tempe Keraton.

Tabel 4. Skor Analisis Kondisi Eksternal

\begin{tabular}{c|l|c}
\hline \multicolumn{2}{c|}{$\begin{array}{c}\text { Analisis lingkungan } \\
\text { eksternal }\end{array}$} & Skor \\
\hline $\mathbf{O}$ & Peluang pasar & 80,00 \\
\cline { 2 - 3 } $\mathbf{T} T$ & $\begin{array}{l}\text { Perubahnya selera } \\
\text { konsumen }\end{array}$ & 17,78 \\
\hline
\end{tabular}

Pada tabel 4 diatas dapat diketahui bahwa diantara beberapa faktor dalam kondisi eksternal yang diidentifikasi, nilai skor yang paling besar faktor pada faktor peluang yaitu "peluang pasar" dengan skor 80,00. Dengan demikian usaha home industry tempe Keraton memiliki kesempatan untuk memanfaatkan peluang yang sangat bagus. Peluang pasar yang bagus tersebut merupakan kesempatan yang dapat dimanfaatkan untuk pengembangan pada home industry tempe Keraton.

Pada faktor yang berupa ancaman terhadap home industry tempe Keraton, yang memiliki nilai skor paling tinggi yaitu 
Perubahan selera konsumen dengan skor 17,78 yang artinya adalah perubahan selera masyarakat sangat mengancam terhadap perusahaan tempe. Perilaku konsumen termasuk dalam hal penting dalam pemasaran, oleh karena itu perubahan keinginan konsumen yang terus dinamis dapat menjadi ancaman dalam pengembangan UMKM (Bernando \& Samosir, 2015). Dengan demikian adanya perusahaan lain yang memproduksi tempe sangat berdampak negatif terhadap usaha home industry tempe tersebut, sehingga perlu perusahaan mewaspadainya, karna dampak yang diakibatkan oleh perusahaan lain sangat berpengaruh terhadap usaha home industry tempe Keraton. Pentingnya dalam menyikapi perubahan selera konsumen termasuk juga strategi dalam suatu strategi yang dapat meningkatkan daya saing melalui volume penjualan dan kepercayaan konsumen (Fitri, 2013).

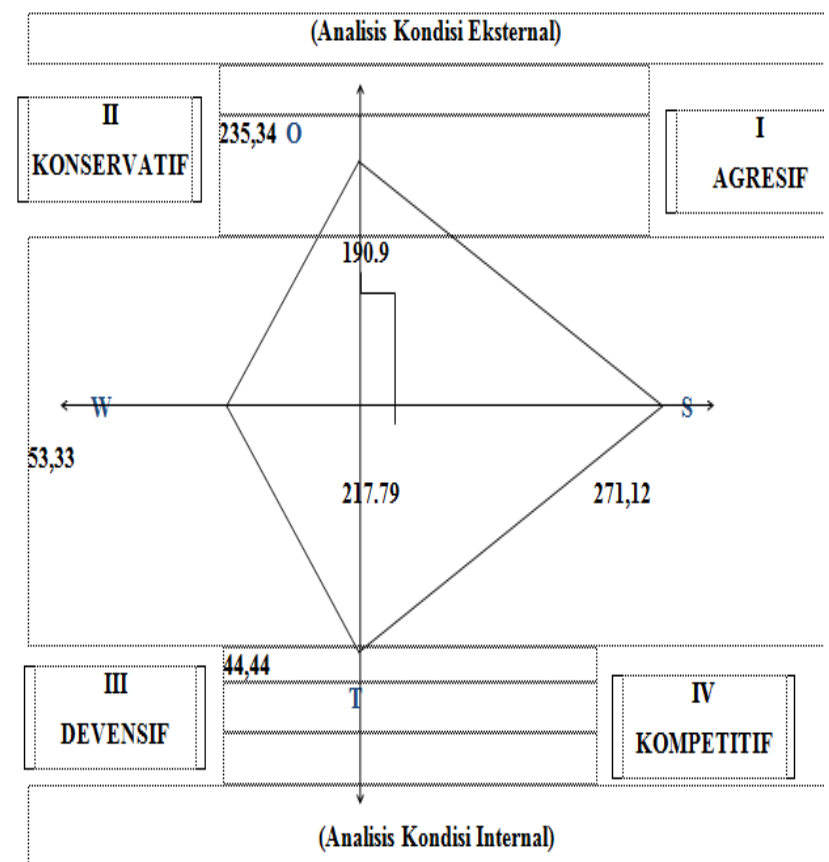

Analisis Kondisi Internal $=271,12-53,33$ $=217.79$

Analisis Kondisi Eksternal $=235,34 \quad-$ $44,44=190.9$
Gambar 1. Keterkaitan kondisi internal dengan kondisi eksternal usaha home industry tempe Keraton

Berdasarkan gambar 1, maka dapat diketahui bahwa nilai dari analisis kondisi internal sebesar 217.79. Adapun nilai dari hasil analisis kondisi eksternal yaitu sebesar 190.9. Berdasarkan besaran nilai analisis kondisi internal dan eksternal maka strategi pengembangan dapat diketahui dengan cara mengurangi antara nilai kekuatan (S) dengan kelemahan (W) untuk analisis kondisi internal dan mengurangi nilai $(\mathrm{O})$ dengan ancaman (T) untuk analisis kondisi eksternal. Hal ini menunjukkan bahwa kekuatan lebih besar dari pada kelemahan sedangkan peluang yang ada masih mampu mengatasi ancaman. Agar perumusan strategi dapat lebih mudah maka langkah selanjutnya adalah menentukan analisis kondisi internal dan analisis kondis eksternal.

\section{Kesimpulan}

Berdasarkan hasil penelitian yang dilakukan terhadap home Indusry tempe Keraton dapat di tarik kesimpulan bahwa strategi pengembangan usaha Home Indusry tempe, adalah strategi agresif yaitu meningkatkan manajemen serta jumlah dan kualitas produksi untuk mendapatkan kepercayaan dari konsumen.

\section{DAFTAR PUSTAKA}

Bernando, C., \& Samosir, H. (2015). Jurnal Pengaruh Persepsi Harga Dan Promosi Terhadap Keputusan Pembelian Konsumen Produk Enervon-C, 1(November), 1-14.

Fitri, R. (2013). Pengemasan dan Pelabelan. Biomaterials.

Kristanto, T., Muliawati, E. C., Arief, R., \& Hidayat, S. (2018). Peningkatan 
Journal of Food Technology and Agroindustry Volume 2 No 2 Agustus 2020

P-ISSN: 2656-0623

E-ISSN: 2684-8252

Kualitas Produksi UKM Percetakan di Karangpilang Surabaya dan Krian Sidoarjo. AKSIOLOGIYA : Jurnal Pengabdian Kepada Masyarakat, 2(1), 33-38.

https://doi.org/10.30651/aks.v2i1.1200

Ling, A. (2013). PADA USAHA MIKRO

KECIL MENENGAH ( STUDI

DESKRIPTIF PADA RUMAH

MAKAN PALEM ASRI SURABAYA

). Jurnal AGORA, l(1).

Manurung, R. DA, \& Aryani, S. (2017).

Pendampingan Psikologi Kesehatan Kerja POS Upaya Kesehatan Kerja (UKK) Nelayan Tradisional Tanjung Peni Citangkil Cilegon. JAM Jurnal Abdi Masyarakat, J, 2(2), 1-6.

Noor, S. (2014). Penerapan Analisis Swot dalam Menentukan Strategi Pemasaran Daihatsu Luxio di Malang. Jurnal INTEKNA, 14(2), 102-209.

Rangkuti, Fredy. (2006). Riset Pemasaran. Gramedia: Jakarta

Riska, F. F., Primyastanto, M., \& Abidin, Z. (2015). Strategi Pengembangan Usah Budidaya Ikan Lele (Clarias sp.) Pada Usaha Perseorangan "Toni Makmur" Di Kawasan Agropolitan Desa Kauman Kecamatan Ngoro Kabupaten Jombang Jawa Timur. Jurnal EEECSOFiM, 3(1), 48-54.

Wilandari, N. I. (2010). Penentuan Agribisnis Unggulan Komoditi Pertanian Berdasarkan Nilai Produksi Di Kabupaten Grobogan. 